\title{
Chronic Dacryocystitis: Clinico-Bacteriological Profile and its Antibiogram at a Tertiary care Hospital in Belagavi, Karnataka
}

\author{
Sreedevi Hanumantha ${ }^{1}$, Deepti S. Patil ${ }^{2}$, Trupti B. Naik ${ }^{3 *}$ (iD \\ and Vijaykumar Mane ${ }^{4}$ iD \\ ${ }^{1}$ Department of Microbiology, Kodagu Institute of Medical Sciences, Madikeri - 571201, Karnataka, India. \\ ${ }^{2}$ Department of Microbiology, SDM College of Medical Sciences and Hospital, Dharwad - 580009, \\ Karnataka, India. \\ ${ }^{3}$ Department of Microbiology, Chamarajanagar Institute of Medical Sciences, Yadapura Village, \\ Kasaba Hobli, Chamarajanagar - 571313, Karnataka, India. \\ ${ }^{4}$ Department of Community Medicine, Koppal Institute of Medical Sciences, Koppal - 583 231, \\ Karnataka, India.
}

\begin{abstract}
Chronic dacryocystitis is an infection of the lacrimal sac and occurs due to obstruction of the nasolacrimal duct. It is an important cause of ocular morbidity in India. Objective: 1) To identify various species of aerobic bacteria causing chronic dacryocystitis 2) To determine the antibiotic sensitivity pattern of these bacterial species. At a tertiary care hospital in Belagavi, Karnataka, over two year period, a cross-sectional study was conducted among 60 patients suffering from chronic dacryocystitis. Samples obtained were subjected to microbiological culture and antibiotic sensitivity testing was done on identified isolates. Statistical analysis was done using Microsoft office excel 2010. The maximum $(31.67 \%)$ number of patients who belonged to the age group of $45-50$ years Female were predominantly affected 50 (83.3\%). Majority i.e. $53(88.34 \%)$ had unilateral eye involvement. Of 67 samples collected 42 (62.68\%) were culture positive. Gram-positive cocci $(65.22 \%)$ were the predominant cause of bacterial infection than Gram-negative bacilli (34.78\%). Among Gram-positive cocci, Staphylococcus aureus (30.43\%) and Streptococcus pneumoniae $(21.73 \%)$ and among Gram-negative bacilli. Pseudomonas aeruginosa and Klebsiella aerogenes (10.86\% each) were the predominant isolates. The most effective antimicrobial agents for Gram-positive cocci were Gentamicin and Vancomycin (93.33\% each) and for Gram-negative bacilli were Ticarcillin/Clavulanic acid (87.25\%), Ticarcillin, Imipenem, and Ceftazidime/ Clavulanic acid ( $81.25 \%$ each). The present study highlights the need for detection of specific etiological agents and their antibiotic sensitivity which will enable the clinician in efficient patient management and avoid irrational antibiotic use.
\end{abstract}

Keywords: Antibiotic sensitivity, chronic dacryocystitis, clinical features, eye infections, lacrimal discharge

*Correspondence: truptinaik01@gmail.com; +91 8217798690

(Received: April 30, 2021; accepted: June 28, 2021)

Citation: Hanumantha S, Patil DS, Naik TB, Mane V. Chronic Dacryocystitis: Clinico-Bacteriological Profile and its Antibiogram at a Tertiary care Hospital in Belagavi, Karnataka. J Pure Appl Microbiol. 2021;15(3):1338-1347. doi: 10.22207/JPAM.15.3.24

(C) The Author(s) 2021. Open Access. This article is distributed under the terms of the Creative Commons Attribution 4.0 International License which permits unrestricted use, sharing, distribution, and reproduction in any medium, provided you give appropriate credit to the original author(s) and the source, provide a link to the Creative Commons license, and indicate if changes were made. 


\section{INTRODUCTION}

Dacryocystitis, a common clinical condition, is an inflammation of the lacrimal sac and is attributed to obstruction of the nasolacrimal duct (NLD). NLD obstruction converts the lacrimal sac into the reservoir of infection and any organism that colonizes the nasolacrimal sac could be responsible for infection ${ }^{1}$. Bacterial infection contributes about $60.8-94.9 \%$ of all dacryocystitis ${ }^{2}$ predominantly affecting females ${ }^{3,4}$. Dacryocystitis may be congenital or acquired and acquired dacryocystitis further may be acute and chronic.

Acute dacryocystitis patient complains of watering of the eye, severe pain, redness, and acute onset of swelling over lacrimal sac region with edema spreading over the lower lid and cheek. Streptococcus species is the most commonly implicated organism in acute dacryocystitis. It is treated by systemic antibiotics, anti-inflammatory drugs, and hot compresses ${ }^{3}$. Patients with chronic dacryocystitis make a complaint of continuous watering of the eyes and mucoid or mucopurulent discharge regurgitation on pressure over lacrimal sac area or on irrigation of lacrimal drainage system. It is an important cause of ocular morbidity in India. Frequently isolated organisms in chronic dacryocystitis are Staphylococcus aureus, Streptococcus pneumoniae, $\beta$-hemolytic streptococcus, etc. The definitive treatment of chronic dacryocystitis is achieved by dacryocystorhinostomy (DCR). If not treated in time, it can lead to complications like conjunctivitis, corneal ulcer, acute on chronic dacryocystitis, lacrimal abscess, fistula, marked edema of eyelids, pre-septal and orbital cellulitis, endophthalmitis, and hypopyon.

Over the years, geographical variation in the causative agents of dacryocystitis has been documented ${ }^{3,5-10}$. and also there are reports of change in the causative agents. ${ }^{11}$ Clinical features are not that pathognomonic of the etiological agent. Further, several studies ${ }^{3-5}$ have shown high antibiotic resistance in bacterial pathogens. Therefore, identification of the causative bacterial species along with antibiotic sensitivity testing is required for effective management. With this background, the present study was undertaken.

\section{Aims and Objectives}

1. To identify various aerobic bacterial species causing chronic dacryocystitis in the study setting.

2. To determine the antibiotic sensitivity pattern of these bacterial species.

\section{MATERIALS AND METHODS}

A cross-sectional study was conducted over two years at a tertiary care hospital in Belagavi, Karnataka. A total of 60 cases of clinically diagnosed chronic dacryocystitis, who attended the ophthalmology department of Belagavi Institute of Medical Sciences, Belagavi were selected by simple random sampling and a total of 67 samples were collected from them to be included in the study. A pretested and semi-structured questionnaire was used to collect data from each patient about demographic characteristics like age, gender, occupation, clinical history like chief complaints, duration of illness, treatment history, and past medical history along with laboratory findings.

\section{Exclusion criteria}

Patients with congenital dacryocystitis, acute dacryocystitis, and patients who were on antibiotics in the past one week were excluded.

\section{Collection of sample}

Clinical specimens for bacterial examination were collected from all these 60 (from a total of 67 eyes, as 7 patients had bilateral involvement) clinically diagnosed cases of chronic dacryocystitis after obtaining informed consent. Chronic dacryocystitis patients are the ones with persistent watering of the eyes for longer duration, thickening of the lacrimal drainage system and regurgitation of mucoid and mucopurulent material on pressure over lacrimal sac area or on irrigation of lacrimal drainage system ${ }^{12}$. The patients were asked to wash the face with soap and water, especially around the affected eye, and allowed to air dry. After air drying, under aseptic conditions, three samples were collected with the help of a sterile inoculating loop one after the other, from the lower conjunctival cul-de-sac and everted punctum at the medial canthus of the affected eye, by applying pressure on the lacrimal sac area.

\section{Processing of specimen}

The materials obtained from the first samples were inoculated into $5 \mathrm{ml}$ of brain heart infusion (BHI) broth and after 48 hours of incubation, were sub-cultured on MacConkey 
agar, Chocolate agar, and Blood agar. Second samples were directly inoculated onto the surface of MacConkey agar, Chocolate agar, and Blood agar and incubated under $\mathrm{CO} 2$ tension, to allow growth of capnophilic bacteria. Organisms grown in both samples were identified using standard biochemical reactions ${ }^{13-15}$ and antibiotic susceptibility testing was performed by KirbyBauer disc diffusion method using appropriate antibiotic discs (HIMEDIA, Bombay, India) as per the recommendation of the CLSI. Simultaneously the test was carried out with standard bacterial strains ${ }^{16}$. Direct smears were prepared from third samples on the clean microscopic slide for Gram staining.

\section{Statistical Analysis}

Statistical analysis was done using Microsoft office excel 2010. The data was analyzed and the results were expressed in percentages.

\section{Ethical Clearance}

Obtained from Institutional Ethical Committee, Belagavi Institute of Medical Sciences, Belagavi.

\section{RESULTS}

A total of 60 patients of clinically diagnosed chronic dacryocystitis were included in the study and out of them, 7 had bilateral eye involvement. So a total of 67 samples were collected and processed for microbiological culture and sensitivity.

Table No. 1 depicts the socio-demographic profile of chronic dacryocystitis cases. Majority i.e. 19 (31.67\%) of patients were in the age group of 41 -50 years with the mean age being $48.43 \pm 15.20$ years. Females were predominantly affected 50 (83.3\%) with a female to male ratio of 5:1. Majority i.e. 35 (58.33\%) were farmers by occupation and in most of the cases, $54(90 \%)$ had no other comorbidities. Right eye $31(51.67 \%)$ was found to be affected the most. Fig. 1 shows the distribution of chronic dacryocystitis cases according to age and gender. The highest number of cases was seen among females in almost all age groups as evident from the Figure no 1.

Out of 67 samples that were cultured in the study, the majority i.e. 42 (62.68\%) were positive. Among them, a single bacterium was isolated in

Table 1. Distribution of chronic dacryocystitis cases according to socio-demographic profile $(n=60)$

\begin{tabular}{llcc}
\hline Variables & Classification & $\begin{array}{c}\text { No. of cases } \\
\mathrm{n}\end{array}$ & $\begin{array}{c}\text { Percentage } \\
(\%)\end{array}$ \\
\hline \multirow{2}{*}{ Age (Years) } & $11-20$ & 1 & 1.67 \\
& $21-30$ & 9 & 15 \\
& $31-40$ & 9 & 15 \\
& $41-50$ & 19 & 31.67 \\
& $51-60$ & 5 & 8.33 \\
Gender & $61-70$ & 15 & 25 \\
& $>70$ & 2 & 3.33 \\
Occupation & Male & 10 & 16.67 \\
& Female & 50 & 83.33 \\
& Farmers & 35 & 58.33 \\
Co-morbidities & Homemakers & 23 & 38.33 \\
& Industrial workers & 02 & 03 \\
& Hypertension & 04 & 6.67 \\
& Diabetes mellitus & 01 & 1.67 \\
& Sinusitis & 01 & 1.67 \\
& Normal & 54 & 90 \\
Eye affected & Right & 31 & 51.67 \\
& Left & 22 & 36.67 \\
& Bilateral & 07 & 11.66 \\
& & & \\
& & & \\
& & & \\
& & &
\end{tabular}


39 (92.85\%) samples, while polybacterial growth ( $\geq 2$ bacteria) was demonstrated in 3 (7.15\%) samples. In the samples with polybacterial growth, a mixture of Proteus mirabilis and S. aureus were isolated from one sample, Enterococcus species and Escherichia coli were isolated from the second sample and the third sample yielded a combination of Streptococcus pneumoniae, Enterobacter species, and Methicillin-resistant $S$. aureus (MRSA).

Fig. 2 reveals the spectrum of clinical isolates causing chronic dacryocystitis. As evident from table 4, Gram-positive cocci 30 (65.22\%) were the predominant cause of bacterial infection in chronic dacryocystitis than Gram-negative bacilli 16 (34.78\%). Staphylococcus aureus 14 (30.43\%) was predominantly isolated followed by Streptococcus pneumoniae 10 (21.73), Pseudomonas aeruginosa, and Klebsiella aerogenes each in 5 (10.86\%) samples, CoNS (Coagulase-negative Staphylococci) 4 (8.69\%), Escherichia coli 3 (6.52\%), Proteus mirabilis 2 (4.34\%), Enterococcus, Viridans streptococcus and Enterobacter species in 1 (2.17\%) sample each.

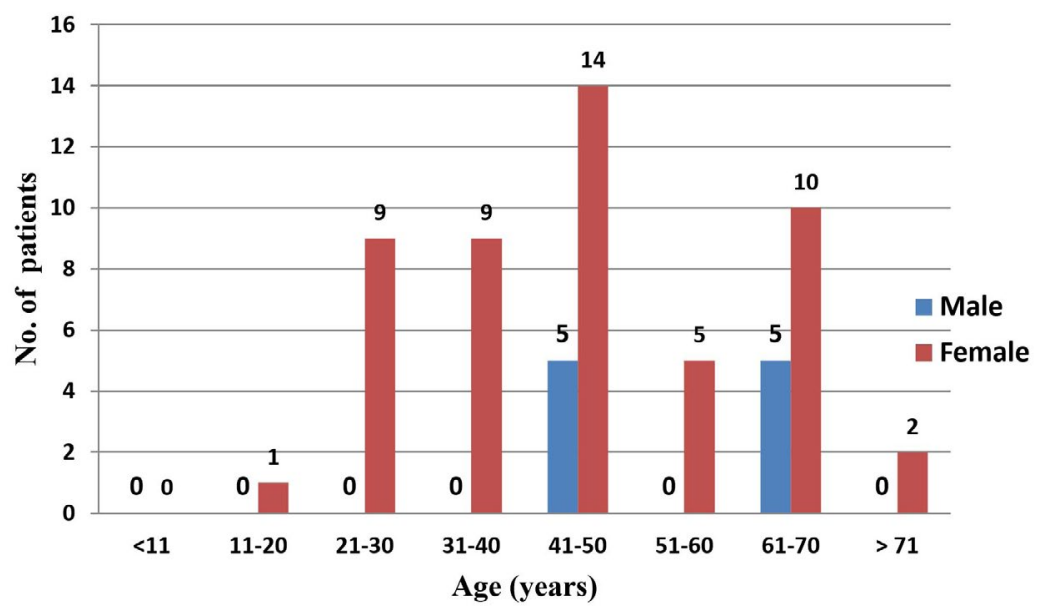

Fig. 1. Distribution of cases according to age and gender $(n=60)$

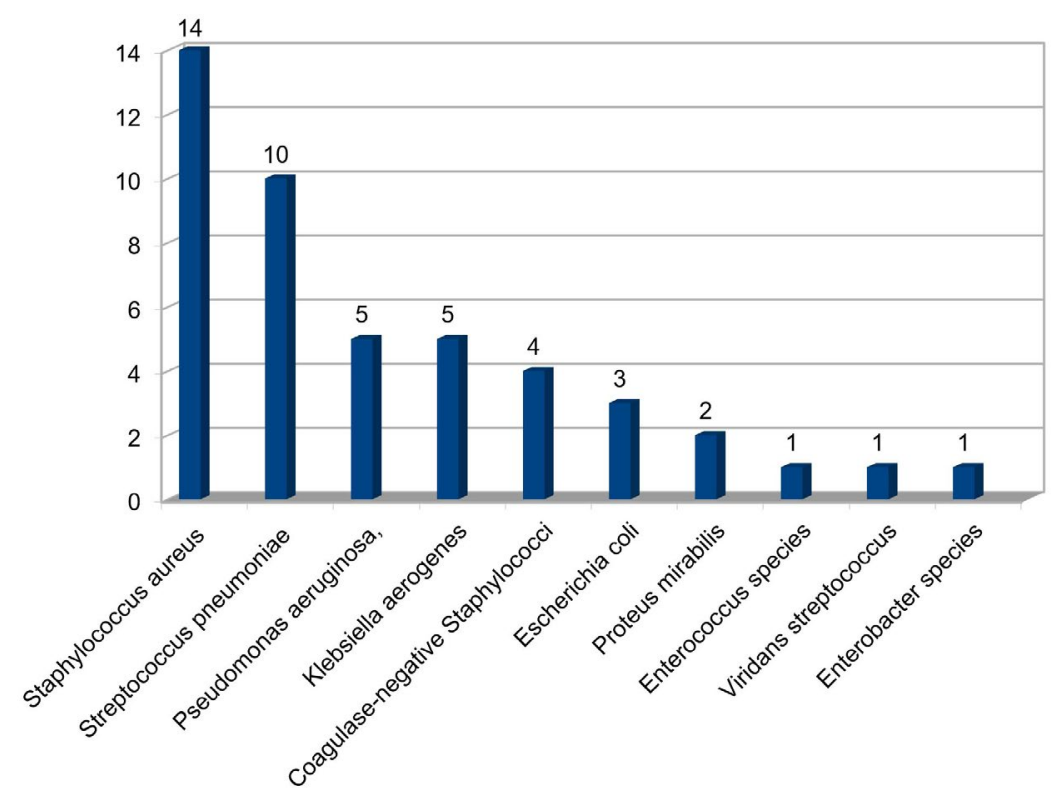

Fig. 2. Spectrum of clinical isolates causing chronic dacryocystitis 
Table 2 depicts distribution of chronic dacryocystitis cases according to clinical signs and symptoms. All the patients had presented with watering of eyes. However, symptoms like fever, ulceration of the eye, intermittent nasal block, and lacrimal abscess were seen in only $1(1.66 \%)$ patient each. Table 3: Distribution of clinical samples according to consistency, color, quantity, and Gram stain findings of discharges.
Most of the patients i.e. 33 (49.2\%) had discharge that was watery in consistency. A large number 31 (46.26\%) of discharges were colorless like water and the majority 34 (50.75\%) were scanty. Both inflammatory cells and bacteria were seen in most 30 (44.78\%) of the Gram stain smears.

Table 5 depicts the antibiotic sensitivity pattern of Gram-positive cocci. 28 (93.33\%) of the clinical isolates of Gram-positive cocci were

Table 2. Distribution of chronic dacryocystitis cases according to Clinical signs and symptoms $(n=60)$

\begin{tabular}{lcc}
\hline Signs and symptoms & $\begin{array}{c}\text { No. of cases } \\
\mathrm{n}\end{array}$ & $\begin{array}{c}\text { Percentage } \\
(\%)\end{array}$ \\
\hline Headache & 03 & 05 \\
Fever & 01 & 1.66 \\
Intermittent nasal block & 01 & 1.66 \\
Minor injury to the affected eye & 02 & 3.33 \\
Watering of eyes & 60 & 100 \\
Intermittent discharge of pus from the affected eye & 04 & 6.66 \\
Localized pain & 03 & 05 \\
Burning sensation of the affected eye & 05 & 8.33 \\
Redness of eye & 02 & 3.33 \\
Ulcer of eye & 01 & 1.66 \\
Swelling over lacrimal sac & 10 & 16.66 \\
Lacrimal abscess & 01 & 1.66 \\
Conjunctivitis & 02 & 3.33 \\
\hline
\end{tabular}

Table 3. Distribution of clinical samples according to consistency, color, quantity, and Gram stain findings of discharge $(n=67)$

\begin{tabular}{llcc}
\hline Properties/ Findings & Classification & $\begin{array}{c}\text { No. of eyes } \\
\mathrm{n}\end{array}$ & $\begin{array}{c}\text { Percentage } \\
\%\end{array}$ \\
\hline Consistency & Watery & 33 & 49.2 \\
& Purulent & 16 & 23.9 \\
& Mucopurulent & 14 & 20.9 \\
Colour & Mucoid & 04 & 06.0 \\
& Colorless (like water) & 31 & 46.26 \\
Quantity on gentle pressure & Yellow & 19 & 28.35 \\
& Cream & 09 & 13.45 \\
& Whitish & 08 & 11.94 \\
Gram stain findings & Moderate & 34 & 50.75 \\
& Profuse & 29 & 43.28 \\
& Inflammatory cells & 04 & 05.97 \\
& Bacteria & 15 & 22.39 \\
& Inflammatory cells and bacteria & 30 & 10.44 \\
& None & 15 & 44.78 \\
\hline
\end{tabular}


found sensitive to gentamicin and vancomycin. The lowest sensitivity was shown to penicillin G 6 (20\% strains), erythromycin 13 (43.33\% strains), and ampicillin 14 (46.66\% strains) as shown in the table. Among 14 Staphylococcus aureus isolates, 6 (42.85\%) were found to be MRSA (Methicillin-resistant Staphylococcus aureus). Further Table 6 also depicts the antibiotic sensitivity pattern of Gram-negative bacilli. All the isolates of $P$. aeruginosa were sensitive to ticarcillin and ticarcillin/clavulanic acid. However, all demonstrated resistance to chloramphenicol and erythromycin. Majority i.e. 14 (87.25\%) of the Gram-negative bacilli were sensitive to ticarcillin/ clavulanic acid, followed by ceftazidime/clavulanic acid, imipenem, and ticarcillin 13 (81.25\%) each as shown in the table. The lowest sensitivity was shown to ampicillin and chloramphenicol by only

Table 4. Spectrum of clinical isolates causing chronic dacryocystitis $(n=46)$

\begin{tabular}{lcc}
\hline Organisms & No. & Percentage (\%) \\
\hline Staphylococcus aureus & 14 & 30.43 \\
Streptococcus pneumoniae & 10 & 21.73 \\
Pseudomonas aeruginosa, & 5 & 10.86 \\
Klebsiella aerogenes & 5 & 10.86 \\
CoNS (Coagulase-negative Staphylococci) & 4 & 8.69 \\
Escherichia coli & 3 & 6.52 \\
Proteus mirabilis & 2 & 4.34 \\
Enterococcus species & 1 & 2.17 \\
Viridans streptococcus & 1 & 2.17 \\
Enterobacter species & 1 & 2.17 \\
Total & 46 & 100 \\
\hline
\end{tabular}

Table 5. Antibiotic sensitivity pattern of Gram-positive cocci $(n=30)$

\begin{tabular}{|c|c|c|c|c|c|c|}
\hline Antibiotics & $\begin{array}{l}\text { S. aureus } \\
(n=14)\end{array}$ & $\begin{array}{l}\text { Streptococcus } \\
\text { pneumoniae } \\
\qquad(\mathrm{n}=10) \\
\text { No. }(\%)\end{array}$ & $\begin{array}{l}\text { CoNS } \\
(n=4)\end{array}$ & $\begin{array}{l}\text { Enterococcus } \\
\quad(n=1)\end{array}$ & $\begin{array}{c}\text { Viridans } \\
\text { streptococcus } \\
(n=1) \\
\text { No. (\%) }\end{array}$ & $\begin{array}{l}\text { Total no. } \\
\text { of sensitive } \\
\text { isolates } \\
(n=30) \\
\text { No. (\%) }\end{array}$ \\
\hline Amikacin & $11(78.57)$ & $08(80)$ & 04 (100) & $00(0)$ & $00(0)$ & $23(76.66)$ \\
\hline Ampicillin & $05(35.71)$ & $06(60)$ & $02(50)$ & $00(0)$ & $01(100)$ & $14(46.66)$ \\
\hline Cefazolin & $11(78.57)$ & $08(80)$ & $03(75)$ & $00(0)$ & $00(0)$ & $22(73.33)$ \\
\hline Cefotaxime & 09 (64.28) & $10(100)$ & $04(100)$ & $01(100)$ & $00(0)$ & $24(80)$ \\
\hline Ceftazidime & $06(42.85)$ & $10(100)$ & $03(75)$ & $01(100)$ & $00(0)$ & $20(66.66)$ \\
\hline Cefuroxime & $08(57.14)$ & $08(80)$ & $03(75)$ & $00(0)$ & $00(0)$ & $19(63.33)$ \\
\hline Ciprofloxacin & $05(35.71)$ & $10(100)$ & $04(100)$ & $00(0)$ & $00(0)$ & $19(63.33)$ \\
\hline Clindamycin & $12(85.71)$ & $08(80)$ & 04 (100) & $01(100)$ & $00(0)$ & $25(83.33)$ \\
\hline Chloramphenicol & $10(71.42)$ & $08(80)$ & $00(0)$ & $01(100)$ & $01(100)$ & $20(66.67)$ \\
\hline Cotrimoxazole & $10(71.42)$ & $06(60)$ & $02(50)$ & $00(0)$ & $00(0)$ & $18(60)$ \\
\hline Erythromycin & $05(35.71)$ & $06(60)$ & $02(50)$ & $00(0)$ & $00(0)$ & $13(43.33)$ \\
\hline Gentamicin & $12(85.71)$ & $10(100)$ & $04(100)$ & $01(100)$ & $01(100)$ & $28(93.33)$ \\
\hline $\begin{array}{l}\text { Netilmicin } \\
\text { sulphate }\end{array}$ & $10(71.42)$ & $10(100)$ & $04(100)$ & $00(0)$ & $00(0)$ & $24(80)$ \\
\hline Ofloxacin & $09(64.28)$ & $06(60)$ & $01(25)$ & $00(0)$ & $00(0)$ & $16(53.33)$ \\
\hline Penicillin G & $0(0)$ & $06(60)$ & $00(0)$ & $00(0)$ & $00(0)$ & $06(20)$ \\
\hline Tetracycline & $12(71.42)$ & $06(60)$ & $03(75)$ & $00(0)$ & $00(0)$ & $21(70)$ \\
\hline Teicoplanin & $10(71.42)$ & $06(60)$ & $02(50)$ & $00(0)$ & $00(0)$ & $18(60)$ \\
\hline Vancomycin & $13(92.85)$ & $09(90)$ & 04 (100) & $01(100)$ & $01(100)$ & $28(93.33)$ \\
\hline
\end{tabular}


$2(12.5 \%)$ bacilli. One ESBL (Extended-spectrum beta-lactamase) strain was seen in the Escherichia coli isolate.

Among 60 patients, 36 patients were managed conservatively which included topical and oral antibiotics based on antibiotic sensitivity test results, to which they responded well and remained asymptomatic during the study period. When the causative agent was found to be susceptible to antibiotics like ciprofloxacin and gentamicin, which were available for topical administration, one among them was prescribed in the form of eye drops. Rest who were resistant to

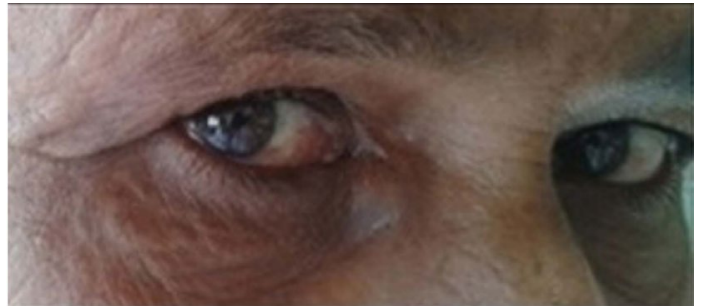

Fig. 3. Patient with chronic dacryocystitis (Right eye) these were treated with oral antibiotics to which they were sensitive. The remaining 24 patients underwent Dacryocystorhinotomy (DCR).

\section{DISCUSSION}

Chronic dacryocystitis is the most common ocular disease seen in all age groups with predominance in the fifth decade. Common causative agents of chronic dacryocystitis include bacteria like $S$. aureus, S. pneumoniae, CoNS, and $P$. aeruginosa, which may vary from region to region and from patient to patient. If the condition is not treated on time, it may lead to various

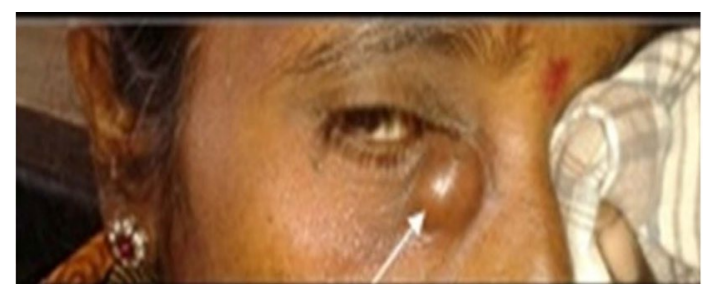

Fig. 4. Patient with lacrimal abscess

Table 6. Antibiotic sensitivity pattern of Gram-negative bacilli $(n=16)$

\begin{tabular}{|c|c|c|c|c|c|c|}
\hline Antibiotics & 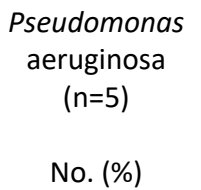 & $\begin{array}{l}\text { Klebsiella } \\
\text { aerogenes } \\
(\mathrm{n}=5) \\
\text { No. }(\%)\end{array}$ & 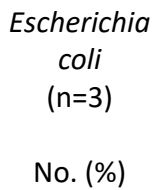 & $\begin{array}{c}\text { Proteus } \\
\text { mirabilis } \\
(n=2) \\
\text { No. (\%) }\end{array}$ & 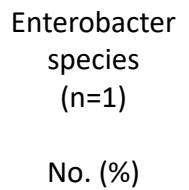 & $\begin{array}{l}\text { Total. } \\
\text { sensitive } \\
\text { isolates } \\
(n=16) \\
\text { No. (\%) }\end{array}$ \\
\hline Amikacin & $03(60)$ & $03(60)$ & $02(66.6)$ & $00(0)$ & $01(100)$ & 09 (56.25) \\
\hline Ampicillin & $01(20)$ & $01(20)$ & $00(0)$ & $00(0)$ & $00(0)$ & $02(12.5)$ \\
\hline Cefazolin & $02(40)$ & $03(60)$ & $00(0)$ & $00(0)$ & $00(0)$ & 05 (31.25) \\
\hline Cefixime & $01(20)$ & $02(40)$ & 01 (33.3) & $00(0)$ & 01 (100) & 05 (31.25) \\
\hline Cefotaxime & $03(60)$ & $03(60)$ & 02 (66.6) & $01(50)$ & $01(100)$ & $10(62.5)$ \\
\hline Ceftazidime & $02(40)$ & $04(80)$ & $02(66.6)$ & 02 (100) & $00(0)$ & $10(62.5)$ \\
\hline $\begin{array}{l}\text { Ceftazidime/ } \\
\text { Clavulanic acid }\end{array}$ & $03(60)$ & $04(80)$ & $03(100)$ & $02(100)$ & $01(100)$ & $13(81.25)$ \\
\hline Cefuroxime & $01(20)$ & $03(60)$ & $00(0)$ & $01(50)$ & 01 (100) & 06 (37.5) \\
\hline Ciprofloxacin & $03(60)$ & $03(60)$ & $00(0)$ & 02 (100) & $00(0)$ & $08(50)$ \\
\hline Chloramphenicol & $00(0)$ & $01(20)$ & $00(0)$ & $01(50)$ & $00(0)$ & $02(12.5)$ \\
\hline Cotrimoxazole & $03(60)$ & $03(60)$ & $02(66.6)$ & $01(50)$ & $00(0)$ & 09 (56.25) \\
\hline Erythromycin & $00(0)$ & $01(20)$ & $01(33.3)$ & $01(50)$ & $00(0)$ & 03 (18.75) \\
\hline Gentamicin & $04(80)$ & $03(60)$ & $02(66.6)$ & $01(50)$ & $01(100)$ & $11(68.75)$ \\
\hline Imipenem & $04(80)$ & $04(80)$ & 03 (100) & $01(50)$ & 01 (100) & $13(81.25)$ \\
\hline Netilmicin Sulphate & $04(80)$ & $03(60)$ & $00(0)$ & $01(50)$ & $00(0)$ & $08(50)$ \\
\hline Ofloxacin & $03(60)$ & $03(60)$ & $01(33.3)$ & $02(100)$ & $01(100)$ & $10(62.5)$ \\
\hline Tetracycline & $02(40)$ & $00(0)$ & 02 (66.6) & $00(0)$ & $01(100)$ & 05 (31.25) \\
\hline Ticarcillin & $05(100)$ & $04(80)$ & $02(66.6)$ & 01 (50) & $01(100)$ & $13(81.25)$ \\
\hline $\begin{array}{l}\text { Ticarcillin/ } \\
\text { Clavulanic acid }\end{array}$ & $05(100)$ & $04(80)$ & $03(100)$ & $01(50)$ & $01(100)$ & $14(87.25)$ \\
\hline
\end{tabular}


complications including endophthalmitis. Hence identification of causative organisms and selection of an appropriate antimicrobial agent is of utmost importance. Besides treating the current infection, it also curbs the emergence of resistant bacteria ${ }^{3-6}$. In our study, the predominant age group affected by chronic dacryocystitis was $41-50$ years $(31.67 \%)$ which is similar to other studies. ${ }^{3,6}$ Female preponderance (83.33\%) was reported in our study which was also noted in other studies ${ }^{3-7,17}$. This could be due to frequent NLD obstruction in females owing to the narrow nasolacrimal canal ${ }^{18,19}$. Further, hormonal changes during menopause, can cause decreased tear production, thereby reducing protection against infections ${ }^{20}$. Our study revealed unilateral (88.33\%) eye involvement, that too right $(51.67 \%)$ eye, which correlates well with other studies $7,10,17$. Dacryocystitis is usually seen in one eye because asymptomatic nasal afflictions are more common on one side ${ }^{21,22}$ and right eye is commonly involved because of narrow bony canal especially in females ${ }^{19}$.

Of 67 samples cultured in our study, 42 $(62.68 \%)$ samples were culture positive. However, Bharathi et $\mathrm{al}^{3}$ recorded $90 \%$, Shah et al. ${ }^{4}$ obtained $100 \%$, Chaudhary et al. ${ }^{5}$ demonstrated $76.66 \%$, Chaudhry et al. ${ }^{6}$ obtained $97.3 \%$, Prakash et al. ${ }^{17}$ found $93 \%$ culture positivity. Our research showed less culture-positive rate and this may be attributed to the fact in the present study samples were collected using a sterile bacteriological loop in comparison to others where sterile swabs were used. Samples were collected with a bacteriological loop with a high degree of precision and accuracy thereby eliminating bacterial colonizers in the vicinity of the canthus.

The present study revealed Grampositive cocci $(65.22 \%)$ as principal causes of bacterial infection in chronic dacryocystitis which closely matches with the observations made by Bharathi et al. ${ }^{3}$, Shah et al. ${ }^{4}$, Pradeep AV et al. ${ }^{6}$, Das et al. ${ }^{9}$ and Prakash et al. ${ }^{17}$ in their studies. The predominant Gram-positive cocci in our research were S. aureus (30.43\%) followed by S. pneumonia (21.73\%) which was in line with other studies ${ }^{2,4,9,17}$. On the contrary, few studies have reported CoNS as the predominant isolate followed by $S$. aureus $s^{3,5}$. Predominant Gram-negative organisms isolated in our study were $P$. aeruginosa and $K$. aerogenes (10.86\%) which were obtained in equal numbers and our study findings correlate well with the findings reported by other studies ${ }^{9,17}$. The source of infection of lacrimal sac could be from the conjunctiva (endogenous) or contaminated eye drops or secondary to other infections like otitis media, rhinitis, stomatitis, etc. The residual bacteria can also act as opportunistic pathogens and known to cause dacryocystitis when a suitable environment sets $\mathrm{in}^{22}$.

In our study antibiotics were selected based on CLSI guidelines for Gram positive and Gram negative organisms and also keeping in mind the local prescriptions of antibiotics. In our research, almost all the Gram-positive cocci were found sensitive to gentamicin and vancomycin (93.33\% each) while maximum resistance was noted for penicillin $\mathrm{G}(80 \%)$, in confirmation with other studies ${ }^{6,17}$. The possible explanation for high sensitivity for vancomycin could be that it is still used as a reserve drug. Penicillin has the upper hand in the development and establishment of resistance against it because it is an age-old drug being widely used, with multiple mechanisms of resistance along with its speedy spread among the patients.

Our research found ticarcillin/clavulanic acid $(87.25 \%)$, followed by ceftazidime/clavulanic acid $(81.25 \%)$, imipenem (81.25\%), and ticarcillin $(81.25 \%)$ as the most effective antibiotics for the majority of Gram-negative bacilli as these drugs are last choice of treatment. One extendedspectrum beta-lactamase (ESBL) producing strains were effectively picked up by using ceftazidime and ceftazidime/clavulanic acid. Prakash et al. ${ }^{17}$ found tobramycin (100\%), gentamicin (100\%) as the most effective antibiotics, and ciprofloxacin as the most resistant. Chaudhary et $\mathrm{al}^{5}$ reported chloramphenicol (90.90\%) and nalidixic acid $(90.90 \%)$ as the most sensitive while ciprofloxacin as the least sensitive. Bharathi et al. ${ }^{3}$ found gatifloxacin $(96.5 \%)$ and ofloxacin $(94.8 \%)$ as the most effective antibiotics but chloramphenicol $(37.3 \%)$ as the least useful antibiotic. There is variation in antimicrobial sensitivity patterns because it differs from one geographical region to other and this may be due to the surfacing of resistant strains as a result of the arbitrary usage 
of antibiotics. Apart from this, the selection of antibiotics is done based on local and regional needs and because of this antibacterial drug profile in the present study has not been found to overlapping with the ones used by other investigators.

\section{CONCLUSION}

The hospital should have its antibiotic policy, based on the local susceptibility profile of area-specific pathogens. Detection of a specific etiological agent followed by a specific antibiotic to which it is susceptible will enable the clinician in efficient patient management and prevents the development of antimicrobial resistance.

\section{ACKNOWLEDGMENTS}

None.

\section{CONFLICT OF INTEREST}

The authors declare that there is no conflict of interest.

\section{AUTHORS' CONTRIBUTION}

SH contributed to the conception of the work and interpretation of the data and drafted the manuscript. DSP collected data and designed tables. TBN compiled data, revised the manuscript, gathered information from the literature. VM statistically analysed and interpret the data.

\section{FUNDING}

None.

\section{DATA AVAILABILITY}

All datasets generated or analyzed during this study are included in the manuscript.

\section{ETHICS STATEMENT}

Ethical Clearance was obtained from the Institutional Ethical Committee, Belagavi Institute of Medical Sciences, Belagavi.

\section{REFERENCES}

1. Sharma S. Ocular infections: Research in India. Indian J Med Microbiol. 2010;28(2):91-94. doi: 10.4103/02550857.62481

2. Luo B, Li M, Xiang N, Hu W, Liu R, Yan X. The microbiologic spectrum of Dacryocystitis. BMC Ophthalmology. 2021;21(1):29. doi: 10.1186/s12886-02001792-4
3.

Bharathi MJ, Ramakrishnan R, Maneksha V, Shivakumar C, Nithya V, Mittal S. Comparative bacteriology of acute and chronic dacryocystitis. Eye. 2008;22(7):953-960. doi: 10.1038/sj.eye.6702918

4. Shah CP, Santani D. A comparative bacteriological profile and antibiogram of dacryocystitis. Nepal J Ophthalmol. 2011;3(2):134-139. doi: 10.3126/ nepjoph.v3i2.5265

5. Chaudhary M, Bhattarai A, Adhikari SK, Bhatta DR. Bacteriology and antimicrobial susceptibility of adult chronic dacryocystitis. Nepal J Ophthalmol. 2010;2(2):105-113. doi: 10.3126/nepjoph.v2i2.3716

6. Chaudhry IA, Shamsi FA, Al-Rashed W. Bacteriology of chronic dacryocystitis in a tertiary eye care center. Ophthal Plast Reconstr Surg. 2005;21(3):207-210. doi: 10.1097/01.IOP.0000161718.54275.7D

7. Baber TF, Masud MZ, Saeed N, Khan MD. An analysis of patients with chronic dacryocystitis. J Post-grad Med Inst. 2004;18(3):424-431

8. Sood NN, Ratnaraj A, Balaraman G, Madhavan HN. Chronic dacryocystitis, a clinico-bacteriological study. J All India Ophthalmol Soc. 1967;15(3):107-110.

9. Delia AC, Uuri GC, Battacharjee K, Das D, Gogoi U. Bacteriology of Chronic Dacryocystitis in the Adult population of Northeast India. Orbit. 2008;27:243-247. doi: 10.1080/01676830802224668

10. Sun X, Liang Q, Luo S, Wang Z, Li R, Jin X. Microbiological analysis of chronic dacryocystitis. Oph-thalmic Physiol Opt. 2005;25(3):261-263. doi: 10.1111/j.14751313.2005.00284.x

11. Pradeep AV, Patil SS, Koti SV, Arunkumar JS, Garag SS, Hegde JS. Clinico-Bacteriological Study of Chronic Dacryocystitis Cases in Northern Karnataka, India. J Clin Diagn Res. 2013;7(11):2502-2504. doi: 10.7860/ JCDR/2013/6636.3590

12. Negm S, Aboelnour A, Saleh T, Yasser M, Hassanin O. Clinicobacteriological study of chronic dacryocystitis in Egypt. Bulletin of the National Research Centre. 2019;43(35):1-7. doi: 10.1186/s42269-019-0074-1

13. Vandepitte J, Engbaek K, Piot P, Heuck CC. Basic laboratory procedures for clinical bacteriology. Geneva, Switzerland: World Health Organisation, Geneva. 1991.

14. Isenberg HD. Essential Procedures for Clinical Microbiology. Washington DC: American Society for Microbiology Press.1998.

15. Forbes B, Sahm D, Weissfeld A. Bailey and Scott's Diagnostic Microbiology. $12^{\text {th }}$ Ed. Philadelphia; Mosby Elsevier. 2007.

16. Clinical Laboratory Standards Institute (CLSI) guidelines. Performance standards for antimicrobial susceptibility testing: Twentieth informational supplement. Document M100-S20. Wayne, PA: Clinical and Laboratory Standards Institute. 2010.

17. Prakash R, Girishbabu RJ, Nagaraj ER, Prashanth HV, Shah J. A Bacteriological study of dacryocystitis. J Clin Diagn Res. 2012;6:652-655.

18. Janssen AG, Mansour K, Bos JJ, Castelijns JA. Diameter of the bony lacrimal canal: normal values and values related to nasolacrimal duct obstruction: assessment with CT. AJNR Am J Neuroradiol. 2001;22:845-850.

19. Struck HG, Hohne C, Tost M. Diagnosis and therapy of 
chronic canaliculitis. Ophthalmologe. 1992;89(3):233236.

20. Smith JE, Reid AP. Asymptomatic intranasal abnormalities influencing the choice of the nostril for nasotracheal intubation. BrJ Anaesth. 1999;83(6):882886. doi: $10.1093 / \mathrm{bja} / 83.6 .882$
21. Bale RN. Dacryocystitis: Bacteriological study and its relation with nasal pathology. Indian J Ophthalmol. 1987;35:178-182.

22. McCulloch JC. Origin and pathogenicity of Pseudomonas pyocyanea in the conjunctival sac. Arch Ophthalmol. 1943;29(6):924-935. doi: 10.1001/ archopht.1943.00880180074006 